\title{
EFFECTS OF HUMAN GROWTH HORMONE IN MAN *
}

\author{
By PHILIP H. HENNEMAN, $\dagger$ ANNE P. FORBES, MARC MOLDAWER, ELEANOR \\ F. DEMPSEY AND EVELYN L. CARROLL \\ (From the Medical Service of the Massachusetts General Hospital and the Department of
Medicine, Harvard Medical School, Boston, Mass.)
}

(Submitted for publication November 2, 1959; accepted April 7, 1960)

Beck, McGarry, Dyrenfurth and Venning (1) first demonstrated activity of purified monkey and human pituitary growth extracts in man and this observation has been confirmed by Ikkos, Luft and Gemzell (2), Raben (3), Pearson, Lipsett, Greenberg and Ray (4), Henneman and Bergenstal and their co-workers $(5,6)$ and others $(7)$. Studies in man have employed pituitary growth extracts prepared by the methods of Raben (8), Wilhelmi, Fishman and Russell (9) and $\mathrm{Li}$ and Papkoff (10). This paper summarizes balance and clinical data from 10 patients treated for 1 day to 24 months with the Raben preparation of human growth hormone $(\mathrm{HGH})$.

\section{METHODS}

Pituitary glands were collected at autopsy, ${ }^{1}$ stored in cold acetone, and extracted by Dr. Maurice Raben (8). ${ }^{2}$ The dry powder appeared to be stable at room tempera-

* Supported by grants from the United States Public Health Service, The American Cancer Society and Ayerst Laboratories.

† Present addresses: P. H. Henneman, Seton Hall College of Medicine, Jersey City, N. J.; M. Moldawer, Baylor Univ. School of Medicine, Houston, Tex. ; E. L. Carroll, Research Inst. for Medicine and Chemistry, Cambridge, Mass.

1 Appreciation is expressed for the cooperation of the Pathology Departments of the following hospitals: Massachusetts General, Beth Israel, Peter Bent Brigham, Deaconess, and Boston City in Boston; the NewtonWellesley in Newton, Mass.; the Rhode Island General and Pawtucket Memorial in Rhode Island; St. Luke's, Mt. Sinai, Presbyterian, Montefiore, Albert Einstein, Roosevelt and Kings County in New York; and Presbyterian, University of Pennsylvania, Temple University and Jefferson Medical School in Philadelphia. The efforts of Drs. Robert. L. Neilsen, Stanley Wallach and Roger Melick in collecting human pituitaries made possible the extent of the studies herein reported.

2 The experiments to be reported owe much to Dr. Raben who prepared the growth extract from human pituitaries and to Drs. Raben, J. C. Beck and O. Pearson who shared their experiences with common lots of Raben extract prior to public presentation of results. ture. It was dissolved in $1.0 \mathrm{ml} 0.1 \mathrm{~N} \mathrm{HCl}$ per $100 \mathrm{mg}$ dry powder (final $\mathrm{pH}$ of solution, about 3.5 ). The solution was diluted with distilled water. Such hydrochloric acid solutions of $\mathrm{HGH}$ maintained their potency after refrigerator storage for at least 6 months. Intramuscular injections of these extracts were painful. Dilution with equal parts of 1 to 2 per cent procaine- $\mathrm{HCl}$ did not decrease effectiveness but rendered the injection painless; such procaine-growth extract preparations pre:ipitated and had to be resuspended by shaking before use. Four lots of growth hormone were used in these studies but no differences between lots were noted.

Ten patients were studied under complete balance conditions. General procedures were as previously described $(11,12)$ except that free access to water was permitted and water intake was measured. Clinical data regarding the patients are presented in Table I. Complete balance data on 7 patients are presented in Figures 1 through 7; data from 2 other patients and the details of change in blood levels of carbohydrate and fat intermediary metabolites are reported elsewhere (13). Balance data on M.A. during $\mathrm{HGH}$ administration confirmed the other studies; they are not presented because bizarre postcontrol data ${ }^{3}$ suggested a systematic error limited to this phase of the study.

The ratios (11) of nitrogen to phosphorus, sodium and potassium in normal muscle and of calcium to phosphorus in normal bone were used to calculate the theoretical balances of the HGH-treated patients.

\section{RESULTS}

Linear growth. Table II shows that the growth rate was definitely stimulated in three patients on prolonged HGH therapy and was probably stimulated in two other patients treated for only one month. The fall in growth rate of S.M., D.Z. and J.C. on stopping $\mathrm{HGH}$ adds further validity to the conclusion that $\mathrm{HGH}$ stimulated growth. The growth rate of D.Z. and J.C. has tended to

3 During 18 days postcontrol urinary nitrogen, phosphorus, sodium and potassium failed to return to forecontrol levels despite lack of other evidence for continuing $\mathrm{HGH}$ effect, for spontaneous resumption of normal growth, for weight change or for undetected change in intake. 
TABLE I

Clinical data on patients

\begin{tabular}{|c|c|c|c|c|c|c|c|c|c|}
\hline \multirow[b]{2}{*}{ Patient } & \multirow[b]{2}{*}{$\begin{array}{c}\text { Chrono- } \\
\text { logical age }\end{array}$} & \multirow[b]{2}{*}{ "Bone age" } & \multirow[b]{2}{*}{ Height } & \multirow[b]{2}{*}{ Weight } & \multirow[b]{2}{*}{$\begin{array}{l}\text { Thyroid } \\
\text { status }\end{array}$} & \multicolumn{2}{|c|}{ Adrenal status } & \multirow[b]{2}{*}{$\begin{array}{c}\text { Other } \\
\text { treatment }\end{array}$} & \multirow[b]{2}{*}{ Diagnosis } \\
\hline & & & & & & $\begin{array}{l}\text { Urine } \\
\text { 17-OHCS* }\end{array}$ & $\begin{array}{l}\text { Water } \\
\text { test } \dagger\end{array}$ & & \\
\hline & $y r s$ & $y r s$ & $i n$. & $l b s$ & & & & & \\
\hline S.M. & 14 & 8.75 & 50 & 53 & See across & 1.6 & & $\begin{array}{l}\text { Triiodo- } \\
\text { thyronine }\end{array}$ & $\begin{array}{l}\text { Craniopharyngioma, } \\
\text { hypopituitarism }\end{array}$ \\
\hline M.A. & 13 & 12 & 55 & 78 & Normal & 0.4 & pos. & & $\begin{array}{l}\text { Craniopharyngioma, } \\
\text { hypopituitarism }\end{array}$ \\
\hline M.C. & 27 & 15.5 & 67 & 109 & Normal & 1.1 & pos. & $\begin{array}{l}\text { Triiodo- } \\
\text { thyronine }\end{array}$ & $\begin{array}{l}\text { Idiopathic hypopituitarism } \\
\text { (since childhood) }\end{array}$ \\
\hline B.D. & 49 & Adult & 68 & 440 & Normal & 4.5 & & & Obesity \\
\hline D.Z. & 9 & 6 & 39 & 31 & Normal & 1.0 & & & $\begin{array}{l}\text { Short stature, delayed bone } \\
\text { age (? hypopituitarism) }\end{array}$ \\
\hline F.D. & 62 & Adult & 69 & 130 & (Cachectic) & (Cachec & ctic) & & Malignant melanoma \\
\hline S.G. & 21 & Adult & 57 & 94 & Normal & $1.717-\mathrm{I}$ & $\mathrm{KS}=3.0$ & & $\begin{array}{l}\text { Short stature, gonadal } \\
\text { dysgenesis }\end{array}$ \\
\hline J.C. $\ddagger$ & 15 & 6 & 50 & 68 & Normal & 0.6 & & & $\begin{array}{l}\text { Short stature, delayed bone } \\
\text { age (? hypopituitarism) }\end{array}$ \\
\hline E.S. & 44 & Adult & 61 & 124 & Normal & 0 & & & Addison's disease \\
\hline L.C. $\ddagger$ & 66 & Adult & 63 & 113 & Normal & 0.5 & & & $\begin{array}{l}\text { Idiopathic hypopituitarism } \\
\text { (onset age 60) }\end{array}$ \\
\hline
\end{tabular}

* Porter-Silber chromagens, mg per 24 hours (14); normal range for adults, 2.0 to $7.5 \mathrm{mg}$ per 24 hours.

$\dagger$ Reference 15.

$\ddagger$ Balance data reported elsewhere (13).

decrease with time on treatment over 21 to 24 months.

Nitrogen metabolism. Nitrogen retention was produced in all patients. Nitrogen retention was slight the first day of treatment with 0.2 to $10 \mathrm{mg}$ $\mathrm{HGH}$ per day; it was maximal (4.5 to $8.0 \mathrm{~g}$ per day) on the third to sixth days of therapy; usually began to wane after 6 to 9 days and retention of 40 to $60 \mathrm{~g}$ of nitrogen; and after 30 days' treatment it was almost undetectable. After 12 days off $\mathrm{HGH}$, Patient B.D. once more responded to $\mathrm{HGH}$ administration with marked nitrogen retention. In general there was slightly greater nitrogen excretion after growth hormone was discontinued than during fore-control, although this "rebound" loss did not match the retention in degree or extent. Nitrogen retention was least marked in S.G. (short stature, gonadal dysgenesis), F.D. (malignant melanoma with cachexia) and E.S. (Addison's disease). No nitrogen retention was produced by $0.1 \mathrm{mg} \mathrm{HGH}$ in S.M.; some retention was produced by $0.2 \mathrm{mg} \mathrm{HGH}$ daily in D. Z., marked retention was produced by 2.5 to $5.0 \mathrm{mg}$ in S.M., M.A., M.C., B.D. and D.Z.; in S.G. and F.D. $10 \mathrm{mg} \mathrm{HGH}$ daily appeared to be more effective than were 2.5 and $5.0 \mathrm{mg}$, respectively. Nitrogen absorption was unaltered by HGH. Fasting blood urea nitrogen decreased 30 to 40 per cent during $\mathrm{HGH}$ administration in four patients, M.A., M.C., B.D. and D.Z. (all of whom showed marked nitrogen retention), and failed to change significantly in Patients S.G. and E.S. (who showed little nitrogen retention). Fasting serum $\alpha$-amino nitrogen was unaltered as compared with postcontrol values in S.M. and F.D. There was a suggestive decrease in urinary total creatinine during HGH in S.M.

Phosphorus metabolism. Phosphorus retention on HGH was due primarily to decrease in urinary phosphorus and paralleled nitrogen retention. Absorption of phosphorus was slightly improved on HGH. Total serum inorganic phosphorus 
TABLE II

Linear growth rate on human growth hormone*

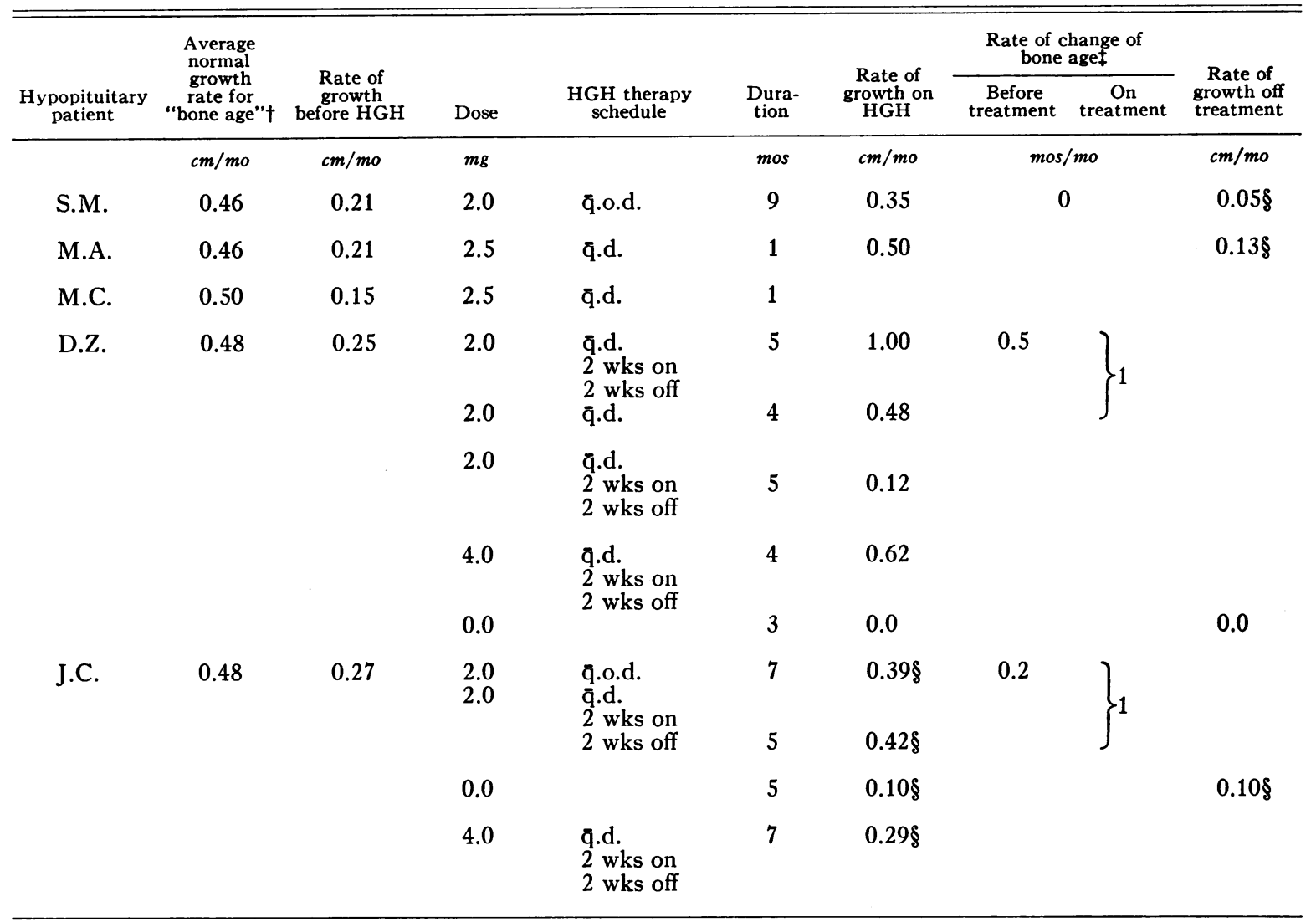

* Growth rate before therapy was calculated over approximately two-year periods. The height measurements represent numerous determinations consistent with each value.

$\dagger$ Reference 16.

$\ddagger$ Bone age evaluation depends upon.size as well as shape of bones. HGH increases size of bones; these data are not adequate to predict whether $\mathrm{HGH}$ will accelerate the maturation and closure of epiphyses.

$\$$ Patients received cortisone, 10 to $25 \mathrm{mg}$ daily, during these periods of observation. Such therapy by itself may further slow the slow rate of growth observed in most children with hypopituitarism (17).

rose significantly in five patients and did not change in two patients (F.D. and S.G.) who similarly showed little nitrogen response.

Calcium metabolism. The changes in calcium metabolism were unique. Calcium retention ( 0 to $400 \mathrm{mg}$ per day) occurred in three patients (B.D., F.D. and D.Z.) during therapy; more marked and more persistent calcium retention occurred after stopping $\mathrm{HGH}$ in four patients (S.M., M.A., S.G. and D.Z.). Indeed, the calcium retention which followed $\mathrm{HGH}$ did not wane within the $30,18,4$, and 12 days of observation off $\mathrm{HGH}$ in Patients S.M., M.A., S.G. and D.Z., respectively. Fecal calcium decreased on $\mathrm{HGH}$ to approximately the same extent that urinary calcium in- creased in six of seven patients so studied. The further retention of calcium following $\mathrm{HGH}$ was due to a decrease in urinary as well as in fecal calcium. It may be significant that increase in urinary calcium occurred in six of seven patients, that B.D. and F.D., with mature skeletons, showed calcium retention during $\mathrm{HGH}$ while S.M., M.A. and D.Z., with open epiphyses, showed calcium retention more marked after $\mathrm{HGH}$ was stopped.

Serum calcium rose slightly in one patient (S.M.) and was unchanged in another (M.C.).

Serum alkaline phosphatase. Serum alkaline phosphatase showed no consistent response during 6 to 36 days of $\mathrm{HGH}$ treatment. 


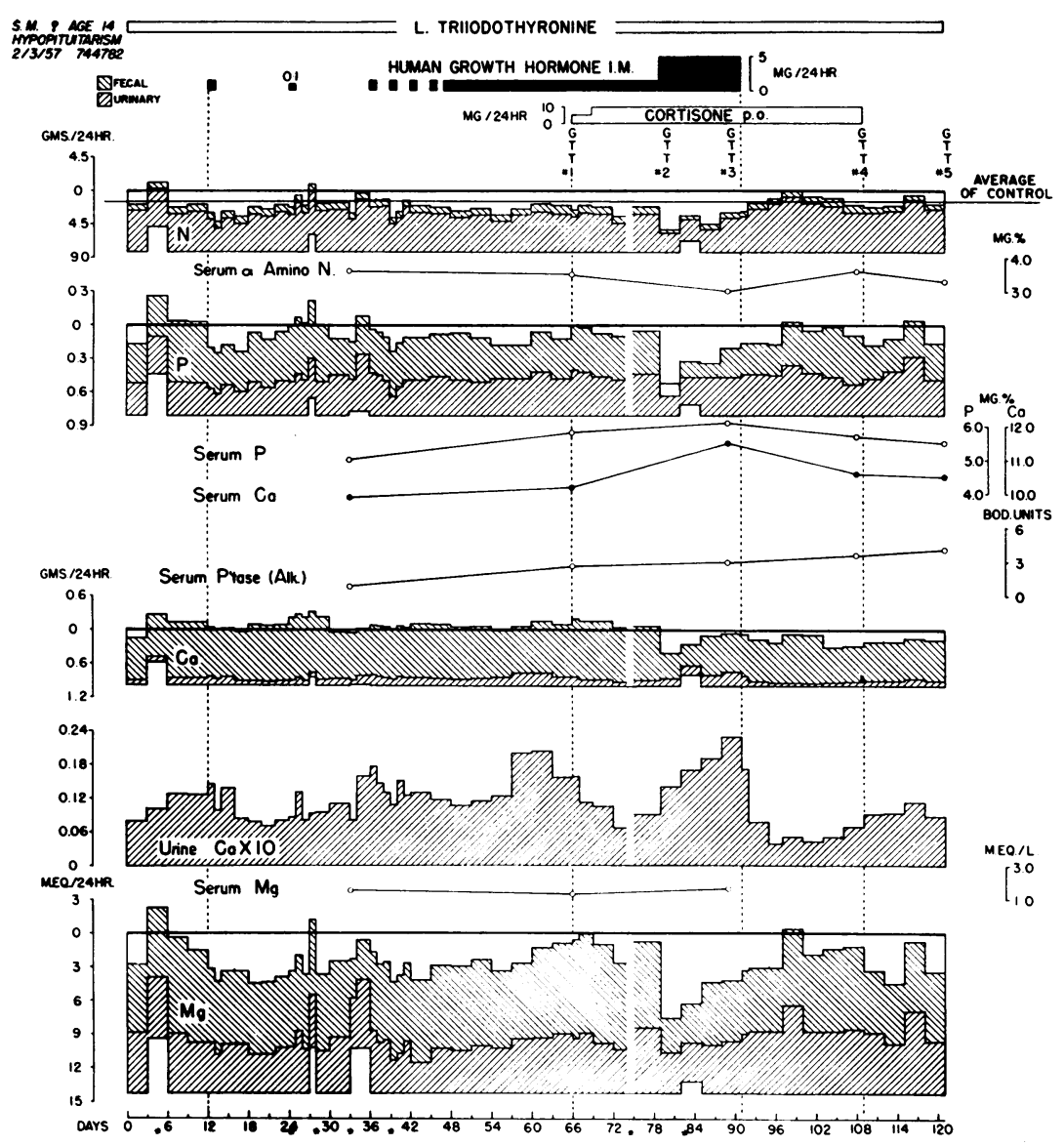

Fig. 1A. EFfect of HGH in S.M., a 14 year old girl with hypopituitarism. Presented are the balance data for nitrogen, phosphorus, calcium and magnesium. The scales are in the same proportion as the proportions in which these constituents are found in most tissues (11). There is a heavy zero line for each substance. The intake is measured down from the zero line: the urinary and then the fecal excretion are charted up from the intake line. Negative balance appears as a hatched area above the zero baseline; positive balance is represented by a clear area below the zero baseline. An ancillary baseline representing the average balance of the fore-control has been superimposed on the nitrogen balance data to facilitate comparison with the treatment and postcontrol periods. $\mathrm{HGH}$ was administered as follows: a single intramuscular injection of $1.0 \mathrm{mg}$ on Day 13 ; after 12 days a single injection of $0.1 \mathrm{mg}$ : after 12 more days injections of $1.0 \mathrm{mg}$ every 3 days; and finally, daily injections of $1.0 \mathrm{mg}$ and then of $5 \mathrm{mg}$. Lot 2 was used throughout the study. The results of the five glucose tolerance tests (G.T.T.) are presented elsewhere (13). The glucose for these tests was withdrawn from the regular glucose ration for that day so that the total caloric intake remained constant. Asterisks under the "days" scale indicate vomitus or refusals, the values for analysis of which were substracted from intake.

S.M.'s growth rate became subnormal at 3 years of age. She underwent partial removal of a craniopharyngioma and pituitary at 7.5 years. At age 11 , studies revealed mild diabetes insipidus, a "bone age" of 8.75 years, urinary 17 -ketosteroids $=$ $0.3 \mathrm{mg}$ per 24 hours, urinary hydroxycorticosteroids (Porter-Silber chromagens) = $1.6 \mathrm{mg}$ per 24 hours, and a negative test for urinary gonadotropins at 6.5 or more mouse units per 24 hours. Thyroid replacement therapy was changed to L-triiodothyronine, $75 \mu \mathrm{g}$ daily, one month prior to this study.

S.M. received $2 \mathrm{mg} \mathrm{HGH}$ (plus thyroid $120 \mathrm{mg}$ and cortisone $25 \mathrm{mg}$ daily and Pitressin Tannate in Oil, $0.5 \mathrm{ml}$ every 3 days) every other day from September, 1957 to April, 1958 when $\mathrm{HGH}$ was discontinued due to the development of nausea, vomiting, headache, appearance of bitemporal hemianopsia and roentgen evidence of further destruction of the sella turcica. Following discontinuation of $\mathrm{HGH}$ these symptoms gradually disappeared and visual fields improved. As of March, 1960 there has been no evidence of further growth of the craniopharyngioma. 


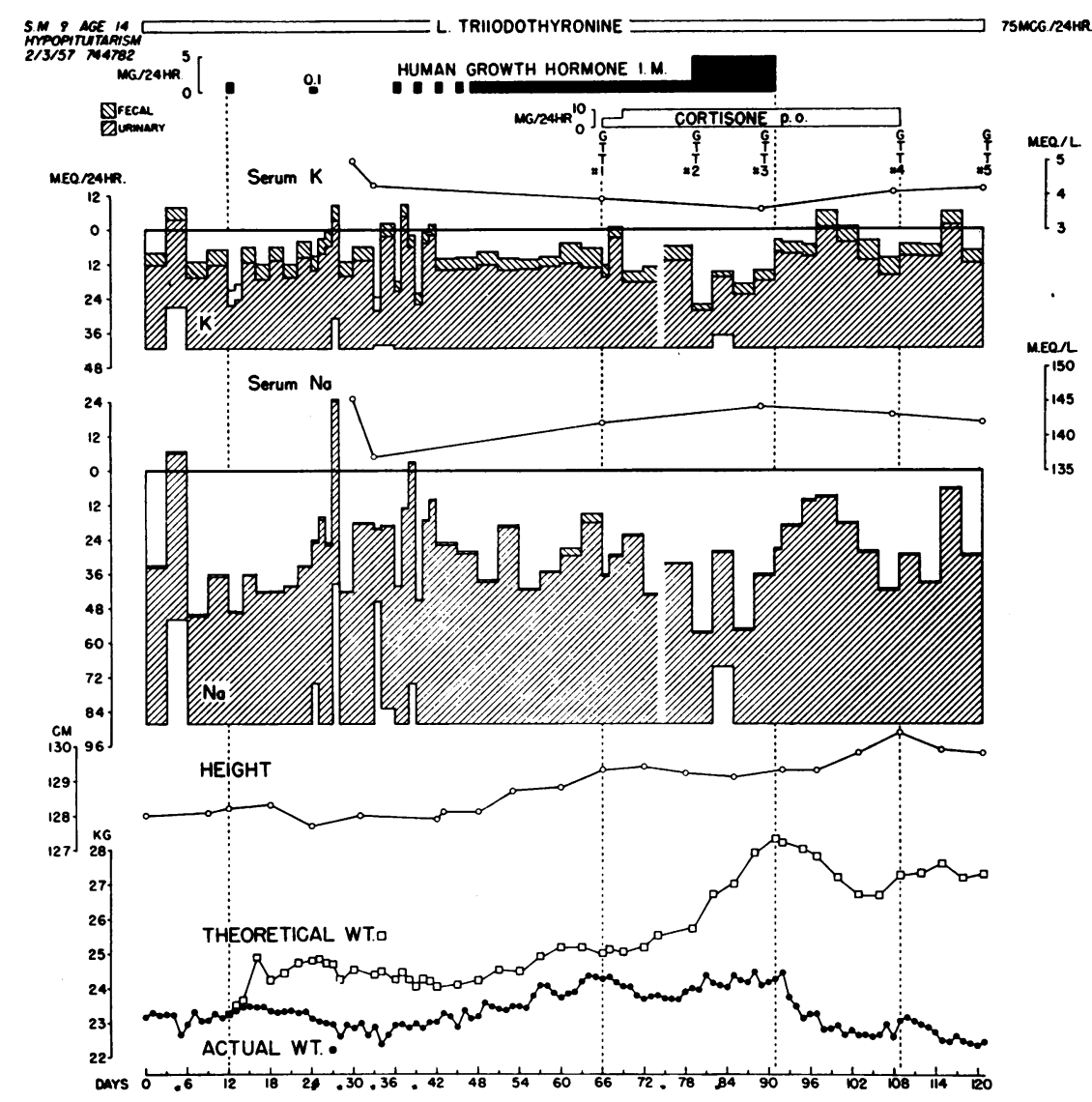

Fig. 1B. Further efFects of HGH in S.M. The theoretical weights in this and subsequent studies are based on the caloric discrepancy of the fore-control plus the weight equivalent (11) of changes in nitrogen, potassium and sodium metabolism on $\mathrm{HGH}$.

Potassium metabolism. HGH induced potassium retention in 10 subjects. The reduction in urinary potassium was usually maximal the first day $^{4}$ of treatment. Potassium retention was slightly greater than that predicted from the nitrogen balance if the $\mathrm{K}: \mathrm{N}$ ratio $=2.5$ of normal muscle (11) is used. Potassium retention was particularly marked the first day on $\mathrm{HGH}$ and it waned on prolonged therapy, as did the nitrogen balance. Fecal potassium was also somewhat less during HGH. Urinary potassium was greater than predicted from the nitrogen excretion the first few days off HGH. This "rebound" was of less magnitude than the total retention during

\footnotetext{
4 However, hourly urinary potassium was not altered during the first eight hours after an injection of $\mathrm{HGH}$ in one subject.
}

$\mathrm{HGH}$, but was similar in magnitude to the retention the first two days on $\mathrm{HGH}$.

Sodium metabolism. Sodium retention regularly occurred on $\mathrm{HGH}$; it was apparent the first day but usually was not maximal until the second or third day of treatment. More milliequivalents of sodium than of potassium were retained. Sodium retention waned on prolonged therapy. On stopping $\mathrm{HGH}$, sodium excretion was increased and the negative sodium balance was equal to or less than the total sodium retained during treatment. HGH decreased urinary sodium excretion in a patient with adrenal insufficiency (E.S.).

Magnesium metabolism. Magnesium retention occurred in four patients on $\mathrm{HGH}$; magnesium balance was unaltered in three. Retention in 


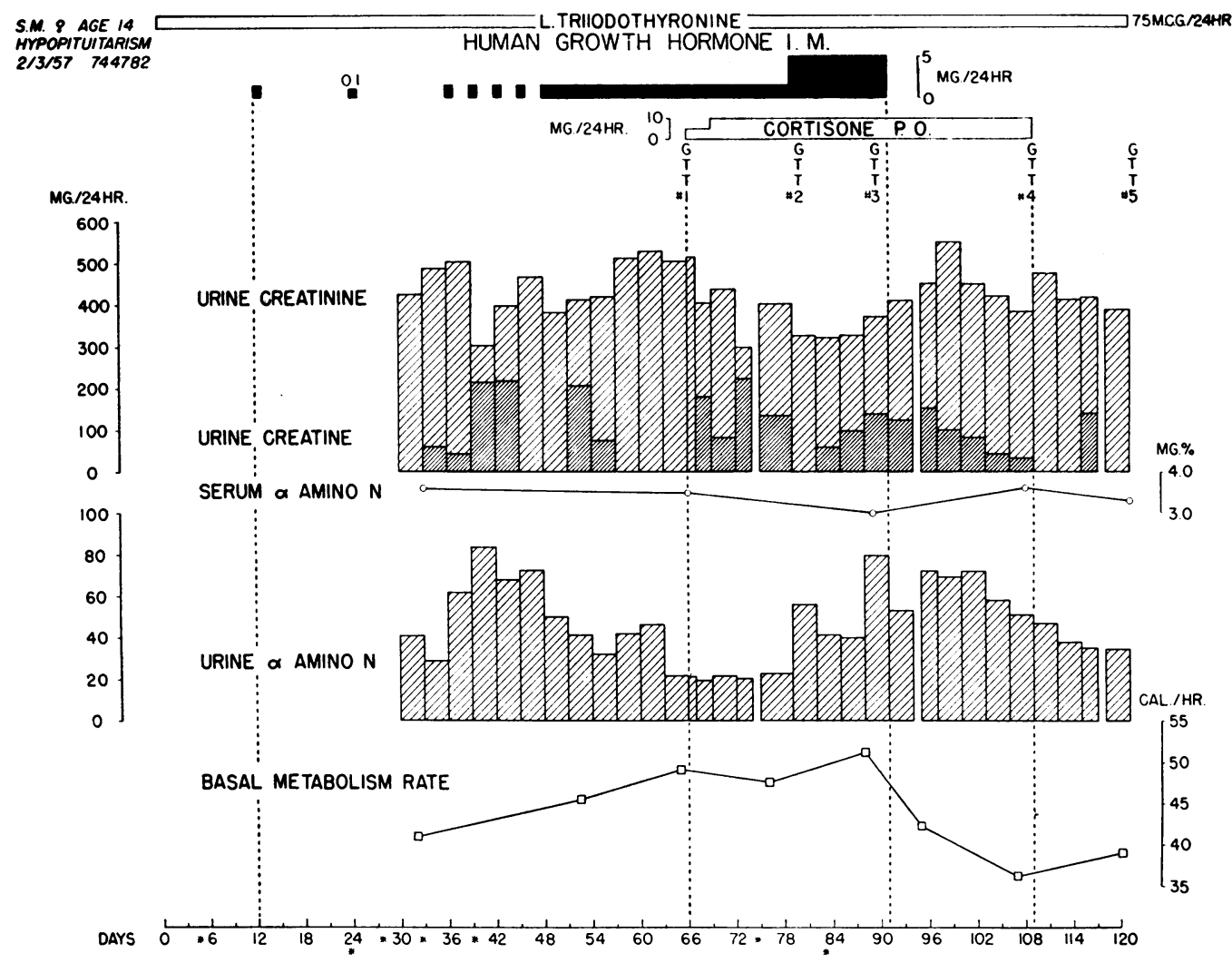

Fig. 1C. Further efFects of HGH in S.M. Variations in serum $\alpha$-amino nitrogen and urinary creatine and $\alpha$-amino nitrogen did not appear related to HGH administration in S.M. (and in M.A.). There may have been a decrease in urinary total creatinine in S.M., particularly on the larger doses of $\mathrm{HGH}$.

each patient was due to a decrease in fecal excretion. Serum magnesium was constant.

Body weight. Weight increased in all patients except those (B.D., F.D. and S.G.) who were on calorically-inadequate diets.

In every experiment the actual weight during HGH therapy was less than the theoretical weight (11) (based on the caloric discrepancy ${ }^{5}$ of the fore-control period plus changes in nitrogen, potassium and sodium balance). A discrepancy between theoretical and actual weight appeared and increased rapidly during the initial phases of

5 The caloric discrepancy represents the daily discrepancy between caloric intake and caloric expenditure. It is calculated on the assumptions that caloric expenditure is constant each day, that the degree of hydration is the same at the beginning and end of calculations, and that fat gain or loss accounts for all weight gain not accounted for by the balances of nitrogen, sodium and potassium.
HGH administration and did not continue to change during postcontrol. If this discrepancy were due to a systematic error or to incorrect factors in calculation, one would expect continued deviation of actual and theoretical weights throughout the postcontrol period.

Basal metabolic rate. The basal metabolic rate,

\section{TABLE III}

Cumulative discrepancy between actual weight and theoretical weight on last day of $H G H$ administration

\begin{tabular}{ccc}
\hline Patient & $\begin{array}{c}\text { Theoretical weight }- \\
\text { actual weight }\end{array}$ & $\begin{array}{c}\text { Duration of } \\
\text { treatment }\end{array}$ \\
\hline & $\mathrm{kg}$ & days \\
S.M. & 4.5 & 78 \\
M.A. & 6.0 & 30 \\
M.C. & 0.5 & 30 \\
B.D. & 3.0 & 42 \\
S.G. & 2.0 & 20 \\
D.Z. & 1.8 & 12
\end{tabular}



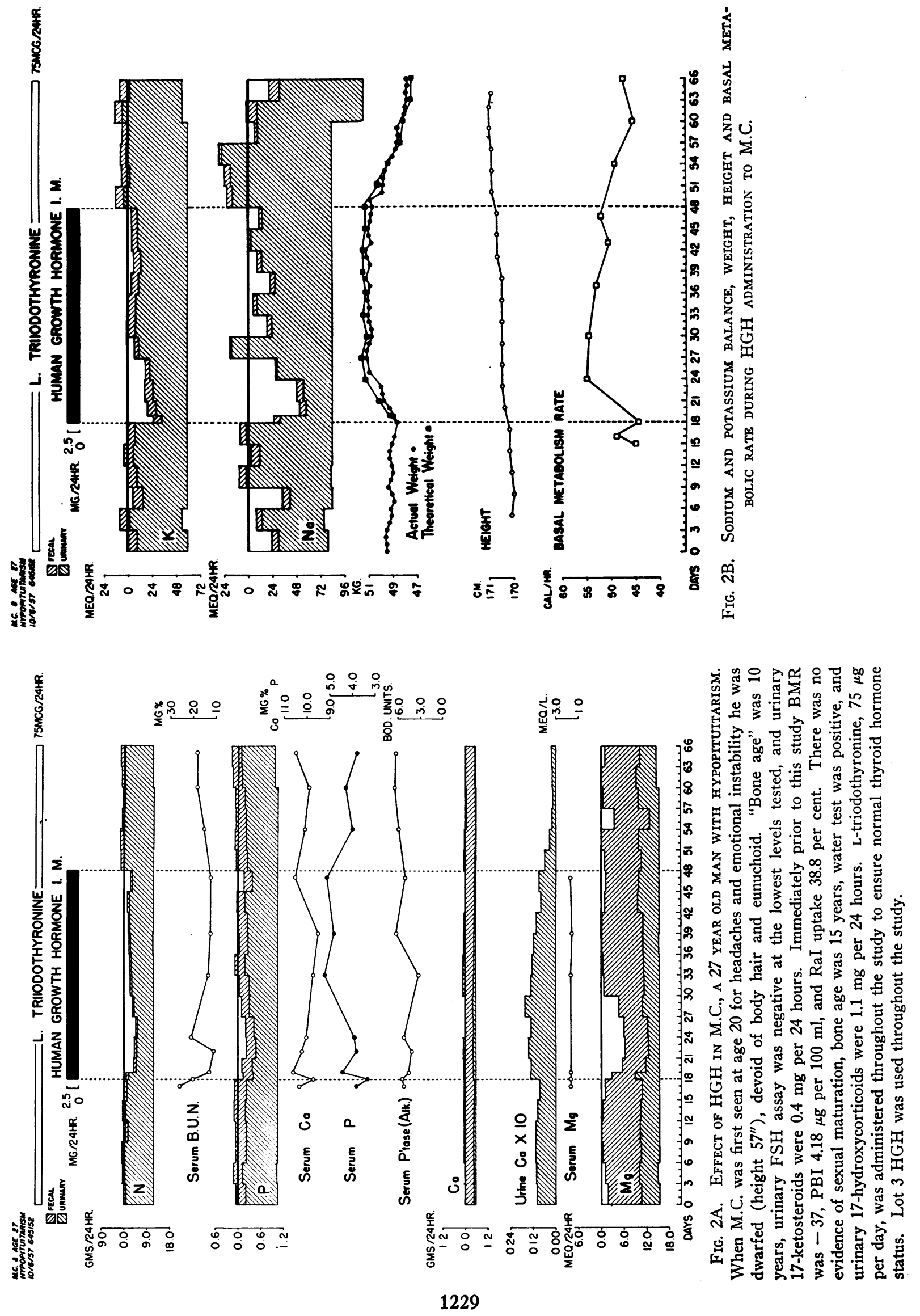
expressed as calories per hours, rose 20 to 25 per cent in the three patients (S.M., M.A. and M.C.) so studied.

Appetite. Beck and associates (1) reported marked anorexia in the first patient treated with large doses of HGH. Mild loss of appetite was reported on direct questioning of each of our subjects. Since loss of appetite is the rule on pro- longed constant diets, it is probably more significant that our patients volunteered that they noted improvement in appetite when $\mathrm{HGH}$ was discontinued. The two patients on prolonged treatment noted mild anorexia on $\mathrm{HGH}$ as compared with appetite during two-week periods off $\mathrm{HGH}$.

Hormone assays. Urinary 17 -ketosteroid and 17-hydroxycorticosteroids, serum protein-bound

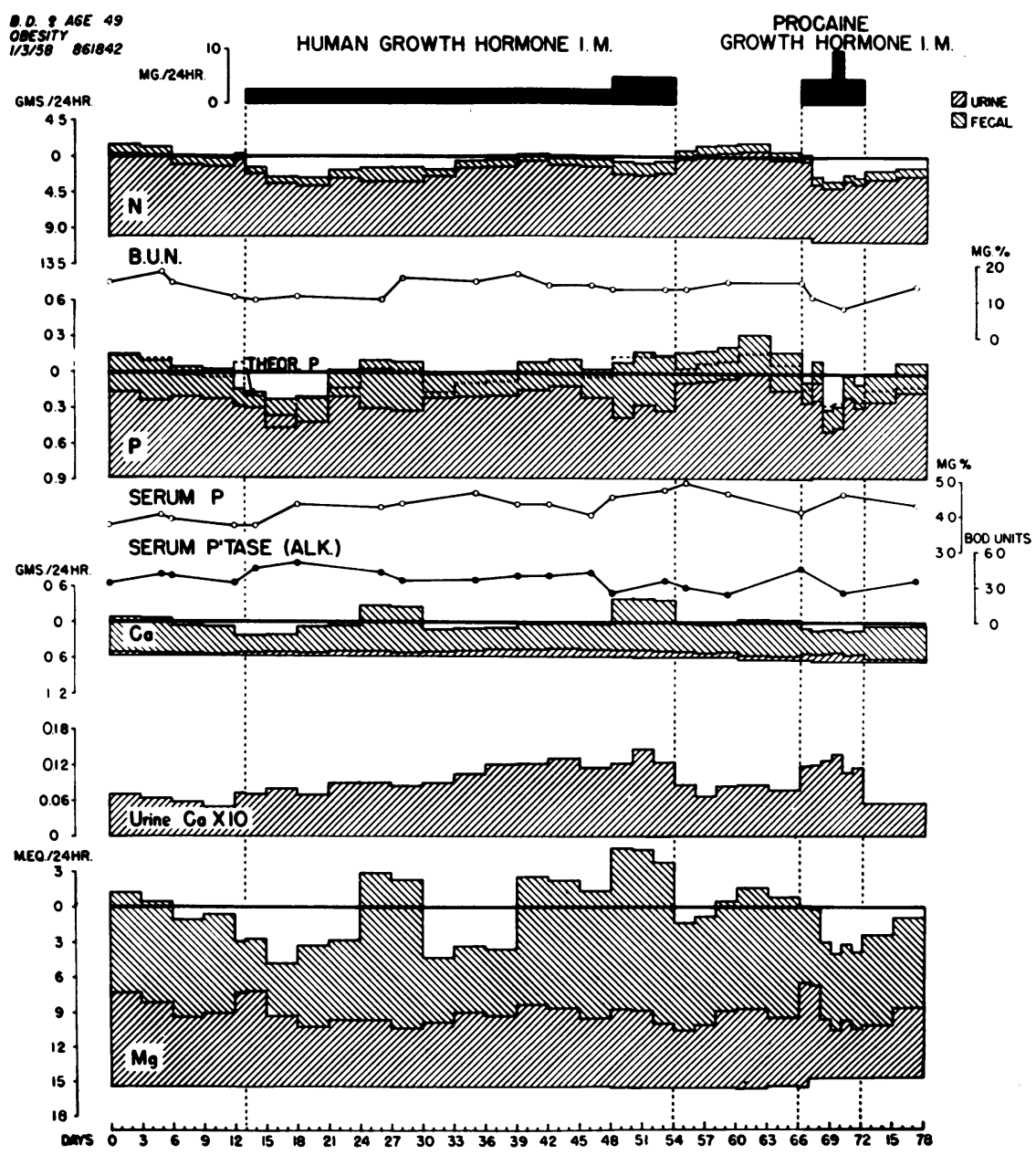

Fig. 3A. The effects of HGH in B.D., a 49 year old woman with Marked oBEsity. Despite a preceding period on the 800 calorie constant diet the patient was still adapting during the 13 days of fore-control as shown by gradually diminishing negative balances. $\mathrm{HGH}$ was given as single daily injections at 6 a.m.; on Day 69 the patient received $5 \mathrm{mg}$ growth hormone at 6 a.m. and at 6 p.m.; on Days 70 and 71 she received $5 \mathrm{mg}$ growth hormone at 6 p.m. The time of administration did not affect the net effects of the hormone. B.D. received Lot $3 \mathrm{HGH}$ Days 12 through 27 and Lot $4 \mathrm{HGH}$ for the remainder of the study. The addition of an equal volume of 2 per cent procaine- $\mathrm{HCl}$ to the $\mathrm{HGH}$ did not decrease its effectiveness. The dotted line on the phosphorus balance represents the "theoretical" phosphorus balance calculated from the nitrogen and calcium balances. 


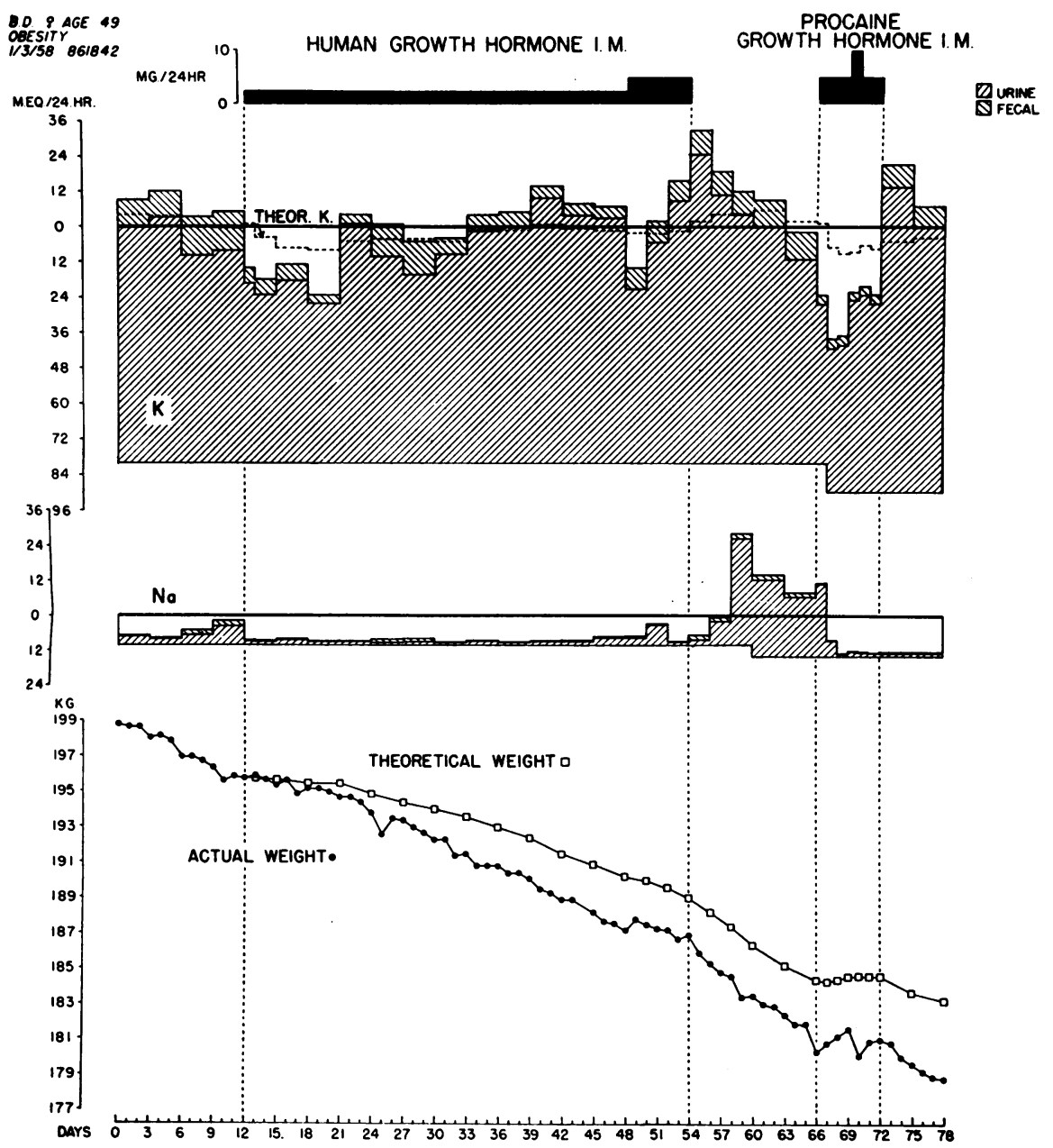

Fig. 3B. Potassium and sodium balances, and Actual and theoretical WEIGHTS DURING HGH administration to B.D. The dotted line on the $\mathrm{K}$ balance represents the theoretical balance predicted from the nitrogen balance. Note in particular the unaccounted-for $\mathrm{K}$ retention on starting $\mathrm{HGH}$ and the unaccounted-for $\mathrm{K}$ loss on stopping HGH. Fasting serum levels of cholesterol, cholesterol esters, total fatty acids and phospholipids were unaltered by $\mathrm{HGH}$ in this patient. The actual weight falls below the theoretical weight and this discrepancy appears during HGH therapy and changes hardly at all when $\mathrm{HGH}$ is discontinued.

iodine and radioiodine uptake were unaltered by $\mathrm{HGH}$ administration in three patients with hypopituitarism. Patient S.M. had mild diabetes insipidus; her constantly dilute urine was not more concentrated during $\mathrm{HGH}$ administration.

Reactions to human growth hormone. Patients complained of mild to moderate pain at the site of intramuscular injections of $\mathrm{HGH}$ dissolved in dilute $\mathrm{HCl}$. Addition of an equal volume of 1 to 2 per cent procaine- $\mathrm{HCl}$ rendered the injections painless. In no patient was a rash or any other sign of allergic reaction noted. Dr. Jacob Lerman (18) found no significant levels of serum precipitins to $\mathrm{HGH}$ in two patients receiving prolonged therapy.

Route and time of injections. S.M. received the growth hormone injections subcutaneously as well as intramuscularly without evident alteration in response. The injections of $\mathrm{HGH}$ in B.D. were administered at 6 p.m. for three days; the 

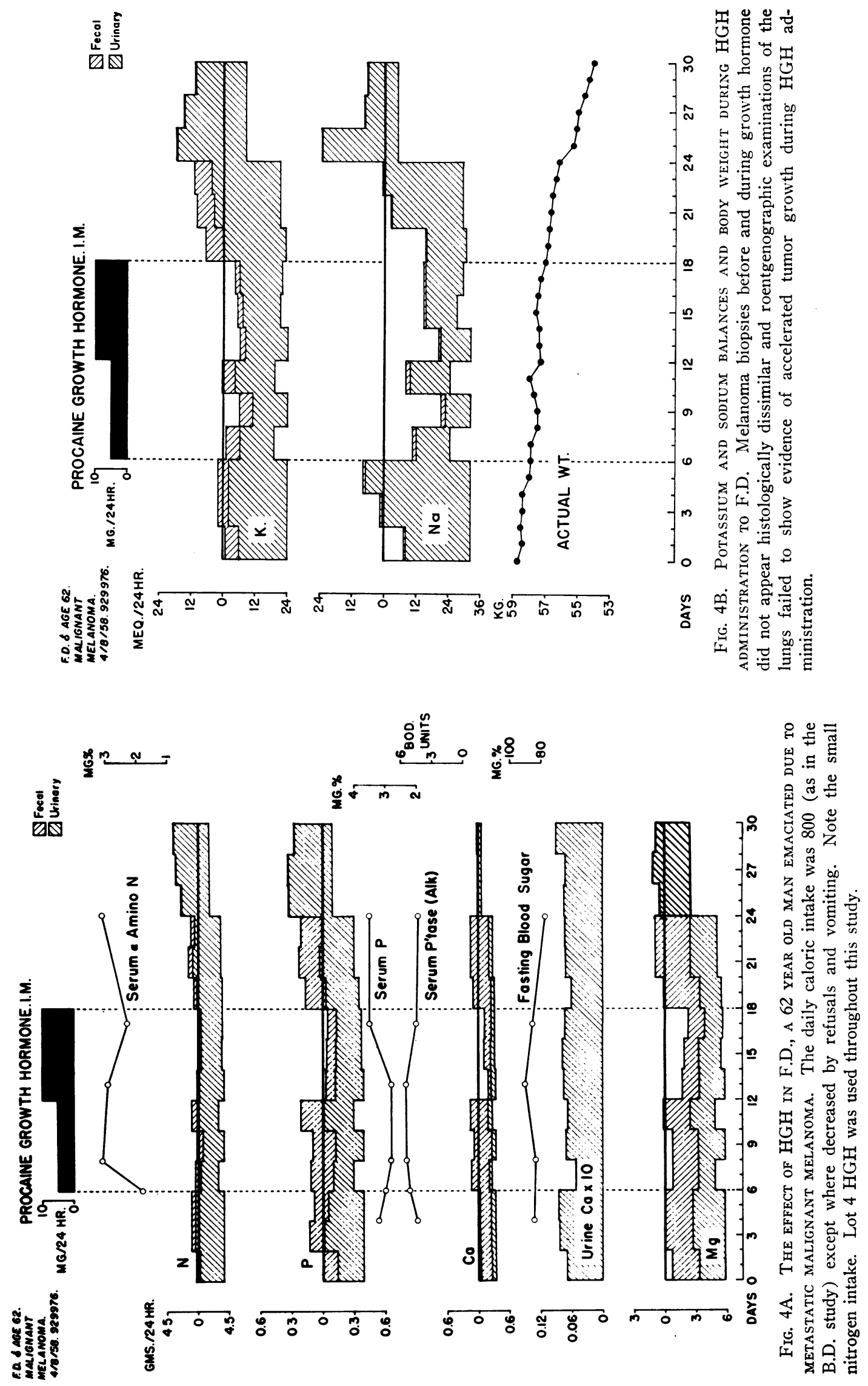


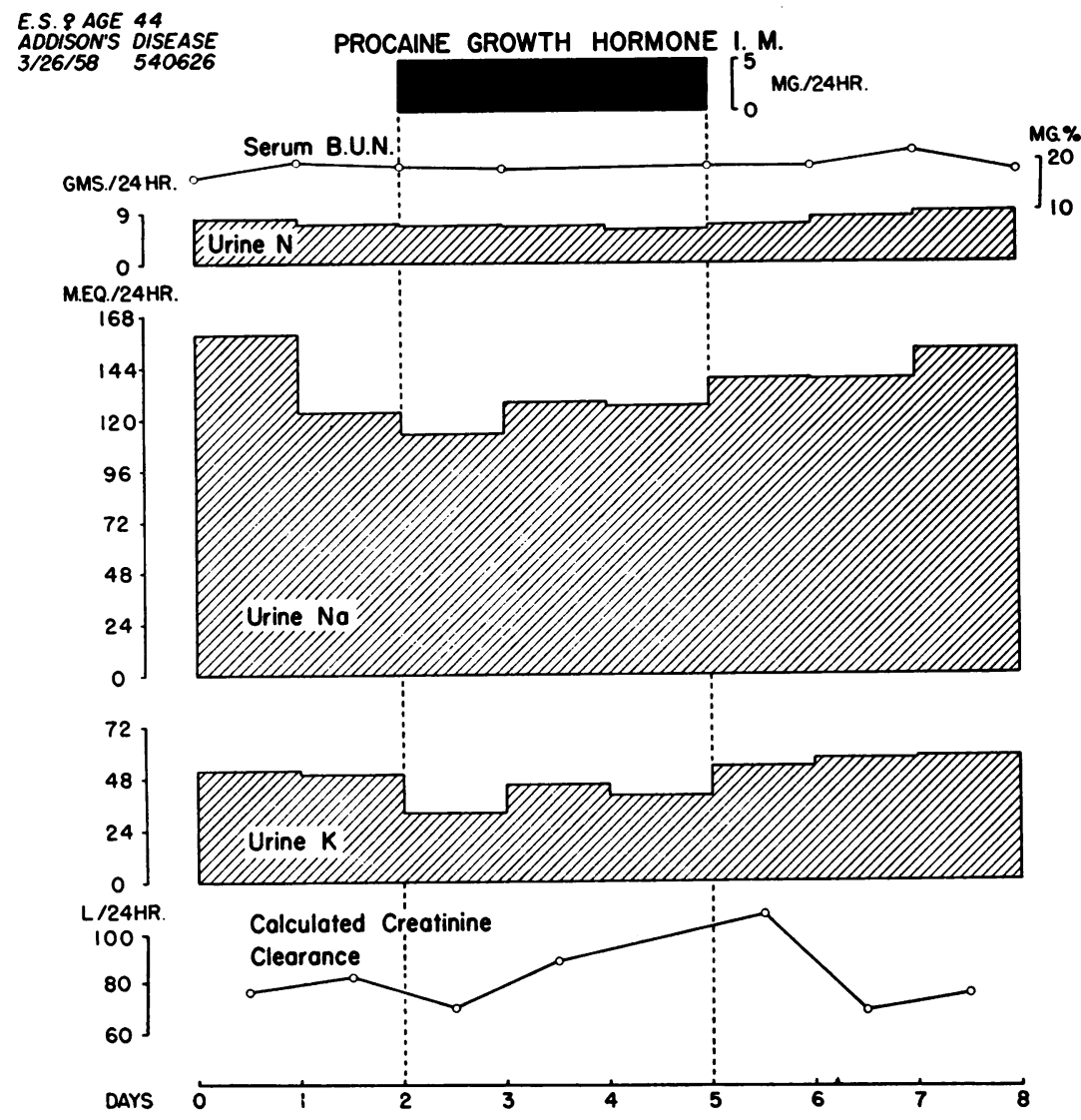

Fig. 5. EfFect of HGH in E.S., a 44 year old woman with Addison's disEASE. E.S. received a constant diet throughout the entire study. No fecal measurements were made. Lot $4 \mathrm{HGH}$ was used throughout this study.

response to evening injections was similar to that observed with early morning injections.

\section{DISCUSSION}

$\mathrm{HGH}$ was effective in ten patients. Linear growth was stimulated in three and probably stimulated in two other of the five patients with open epiphyses. Balance studies revealed retention in all patients of nitrogen, phosphorus, sodium, potassium and calcium in the proportions characteristic of muscle and bone. The most consistent and sensitive indices of response to $\mathrm{HGH}$ were the decreases in urinary nitrogen, sodium and potassium. Weight gain was less than that predicted (17) from the nitrogen, sodium and potassium balances. This discrepancy may reflect in part increased fat catabolism since metabolic rate rose and plasma free fatty acids (13) in- creased. The magnitude of the discrepancy also suggests that the ratio of constituents of normal tissues may not be applicable to hypopituitary patients treated with $\mathrm{HGH}$.

From these studies it would appear that the effective dose of $\mathrm{HGH}$ in the human is more than $0.1 \mathrm{mg}$ per day, that the response to 5 to $10 \mathrm{mg}$ per day is greater than it is to 0.2 to $2.5 \mathrm{mg}$ per day, and that 5 to $10 \mathrm{mg}$ daily produces more rapid nitrogen retention, at least initially, than is usually observed (19) in normal children. Beck's original study suggested that 10 to $80 \mathrm{mg}$ per day of human or monkey growth hormone was excessive in that anorexia, oliguria and transient psychic changes resulted. A single injection of $\mathrm{HGH}$ may alter nitrogen excretion for up to 10 days; after prolonged administration nitrogen retention ceases promptly on stopping HGH. There 
does not appear to be "rebound" excretion of protoplasmic constituents to a degree comparable with the degree of retention during therapy. This suggests that one does not "ungrow" if growth hormone stimulation ceases. By contrast, the nitrogen retained during testosterone therapy is usually lost as quickly as it is retained as soon as therapy ceases.

$\mathrm{HGH}$ was about equally effective in producing nitrogen retention in intact as in hypopituitary patients. Smaller responses were observed in F.D., probably due to lack of dietary calories and body fat stores; in E.S., who had Addison's disease; and in S.G., whose short stature is an unexplained part of gonadal dysgenesis and possibly is due to unresponsiveness to growth hormone. These and other possible explanations for differing responsiveness require further studies for confirmation.

The decreasing effect of $\mathrm{HGH}$ on prolonged administration in man is recorded. It is likely that $\mathrm{HGH}$ initially stimulates rapid retention of nitrogen and other constituents of tissues in a special, perhaps labile, form. Once this require-

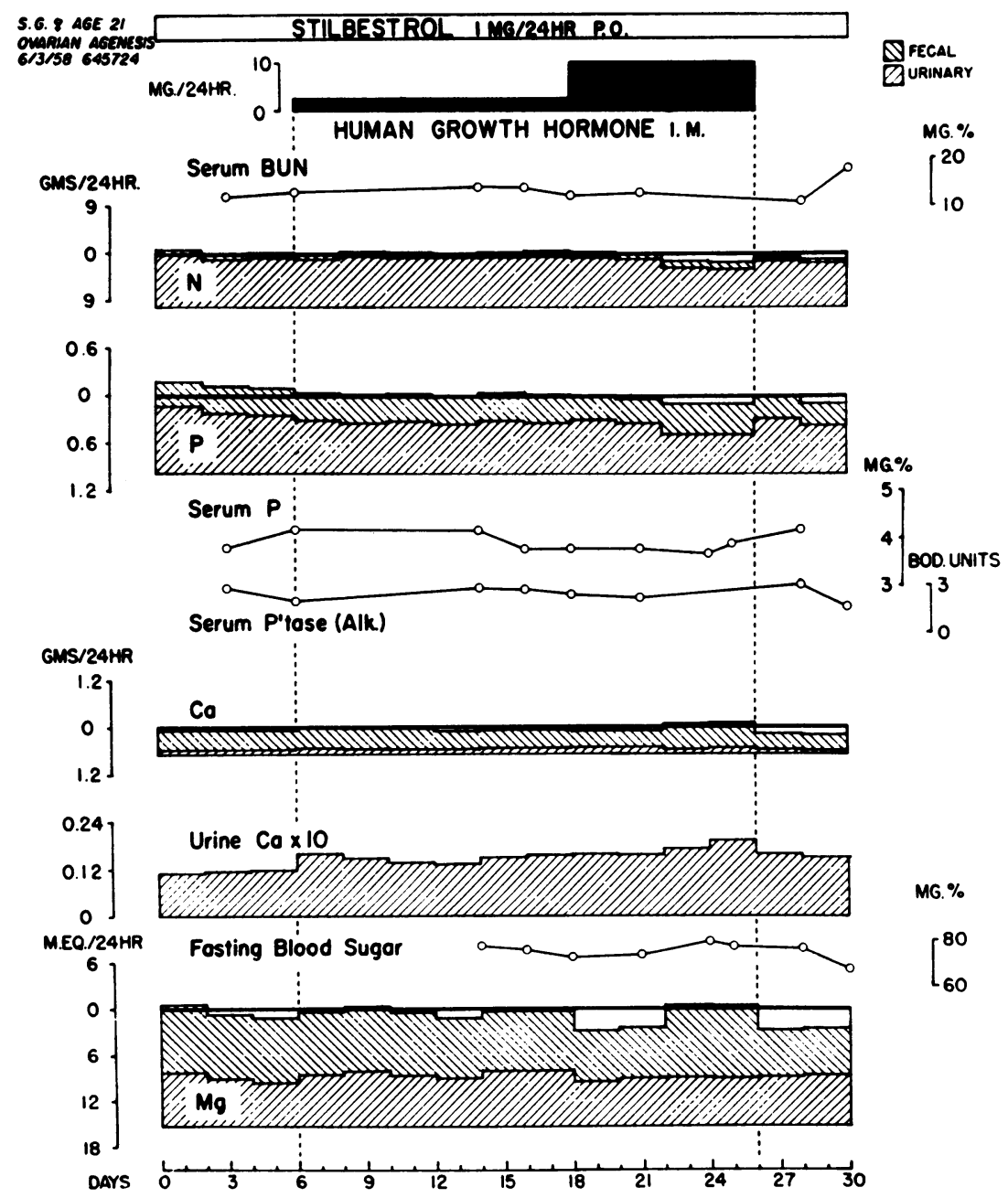

Fig. 6A. EfFect of HGH administration to S.G., a 21 year old patient WITH GONADAL DYSGENESIS. The administration of $2.5 \mathrm{mg} \mathrm{HGH}$ was without measurable effect; administration of $10 \mathrm{mg}$ daily caused slight but definite nitrogen, phosphorus, sodium and potassium retention and rise in urinary calcium. Lot 4 HGH was used on Days 6 through 16; Lot 5 was used thereafter. 


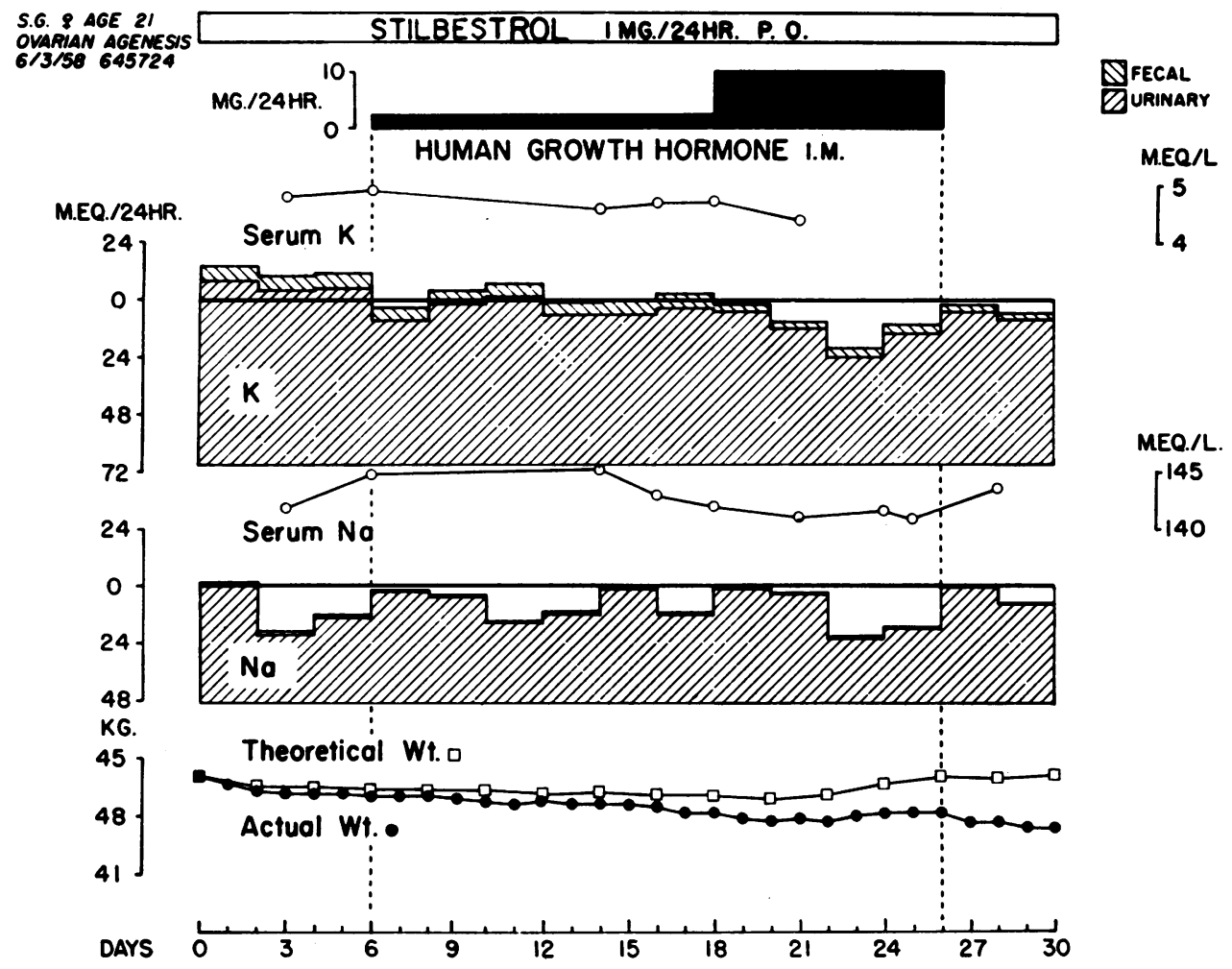

Fig. 6B. Potassium and sodium balance, and actual and theoretical weights during HGH administration to S.G.

ment for growth is met, the rate of nitrogen retention falls to the low rate characteristic of normally growing children (19). The observation in B.D. that a second course of $\mathrm{HGH}$, following 12 days off $\mathrm{HGH}$, again produced very rapid nitrogen retention is unexpected and suggests restoration of some factor(s) when HGH was withdrawn which permits rapid nitrogen retention of brief duration. The phenomenon of early waning of nitrogen retention is probably unrelated to the "plateauing" of growth on more prolonged treatment as recorded in Table II and as reported previously in rats (20). Dr. Jacob Lerman was unable to demonstrate significant serum precipitins to $\mathrm{HGH}$ following treatment in two of the patients in this series (18). Restoration of responsiveness occurred in B.D. after 12 days off HGH ; increasing or maintained resistance after two weeks would be expected if the mechanism of resistance were the formation of neutralizing antibodies. The waning responsiveness to $\mathrm{HGH}$ on prolonged administration raises the possibility that endogenous growth hormone secretion may be cyclical and interrupted rather than continuous. The cement lines of bone are thought to reflect such regular cyclical cessation of growth. The opinion is commonly expressed, although unsupported, that normal children grow in spurts interrupted by phases of fat accumulation.

Calcium retention was greater following rather than during $\mathrm{HGH}$ treatment. Does this mean that $\mathrm{HGH}$ facilitates calcium absorption and chondrogenesis but that osteogenesis and calcium deposition occur only during periods of little or no growth hormone secretion? The hypercalciuria observed during $\mathrm{HGH}$ administration apparently reflects greater stimulation of calcium absorption than of calcium deposition (osteogenesis). It has not been emphasized previously that growth hormone increases calcium absorption; increased calcium absorption was prolonged and did not wane within the 12 to 18 days of observation after stopping HGH.

In addition to potassium retention proportional 
to and coincidental with nitrogen retention, there was observed additional potassium retention the first day on $\mathrm{HGH}$ and similar disproportional loss of potassium the first two days off HGH. This phenomenon is reminiscent of the similar disproportional loss and retention of potassium the first day on and the first day off $\mathrm{ACTH}$, respectively (21). Since growth hormone has anabolic effects opposite in direction to the antianabolic effects of ACTH this unaccounted-for potassium may represent a tissue or process uniquely affected, although in opposite directions, by the anabolic and antianabolic hormones. Batts, Bennett, Garcia and Stein (22) have demonstrated that a part of the potassium retained on growth hormone is accounted for by a rise in concentration of potassium within muscle and that part of the sodium retained contributes to an expansion of extracellular fluid volume. It is of interest that $\mathrm{HGH}$ promotes a simultaneous decrease in urinary sodium and potassium. Some sodium retention was produced by $\mathrm{HGH}$ in E.S. (Addison's disease). Since the degree and type (mineralocorticoid or glucocorticoid) of adrenocortical insufficiency may

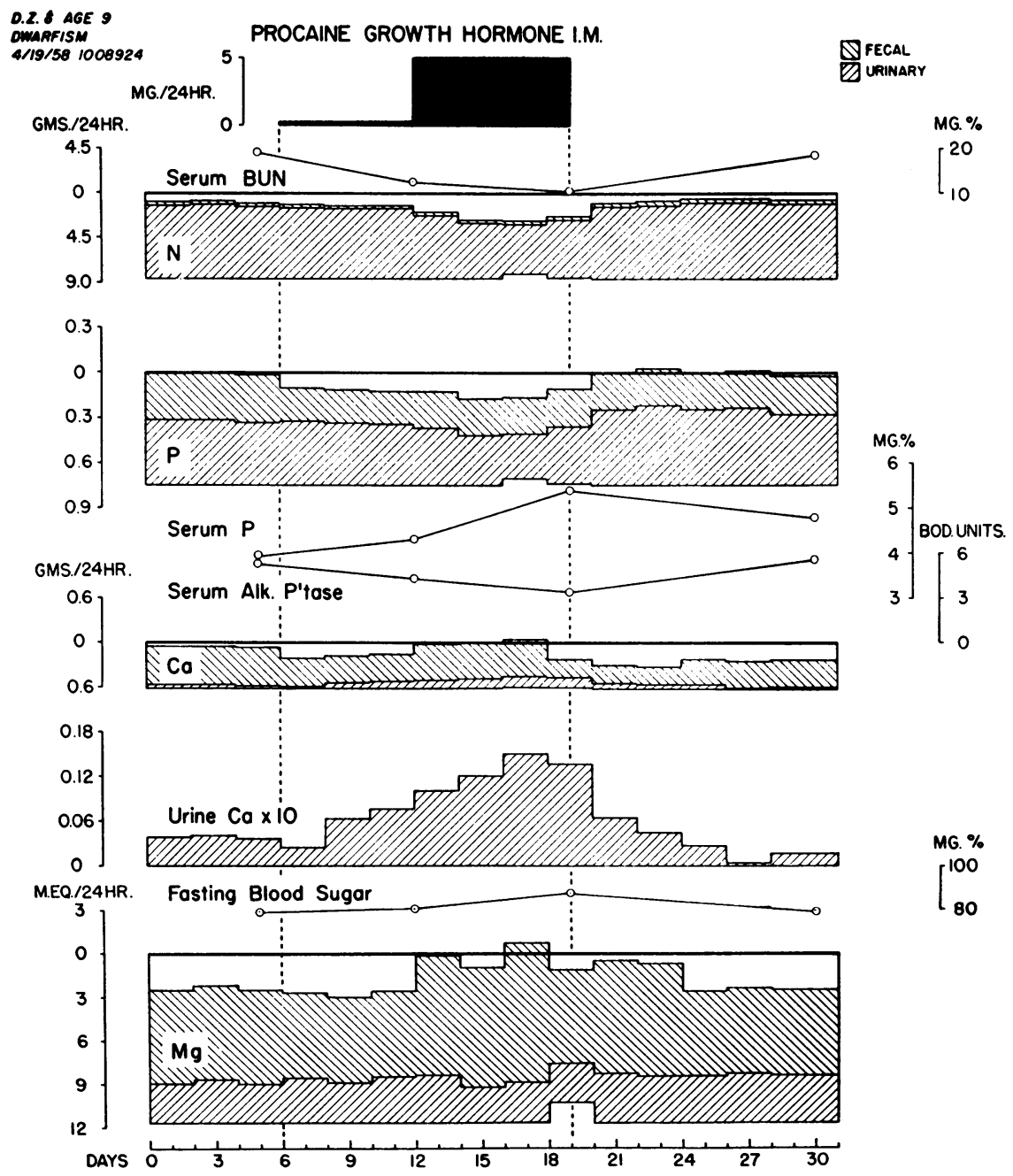

Fig. 7A. EFfects of HGH in D.Z., a Nine yeAR Old boy with SHORT stature AND DELAYED "BONE AGE." Initial doses of $0.2 \mathrm{mg}$ procaine-HGH daily produced nitrogen, phosphorus, sodium and potassium retention and rise in urinary calcium less marked than that produced by $5 \mathrm{mg}$ daily. Lot $4 \mathrm{HGH}$ was used on Days 6 through 14 ; Lot $2 \mathrm{HGH}$ was used thereafter. 


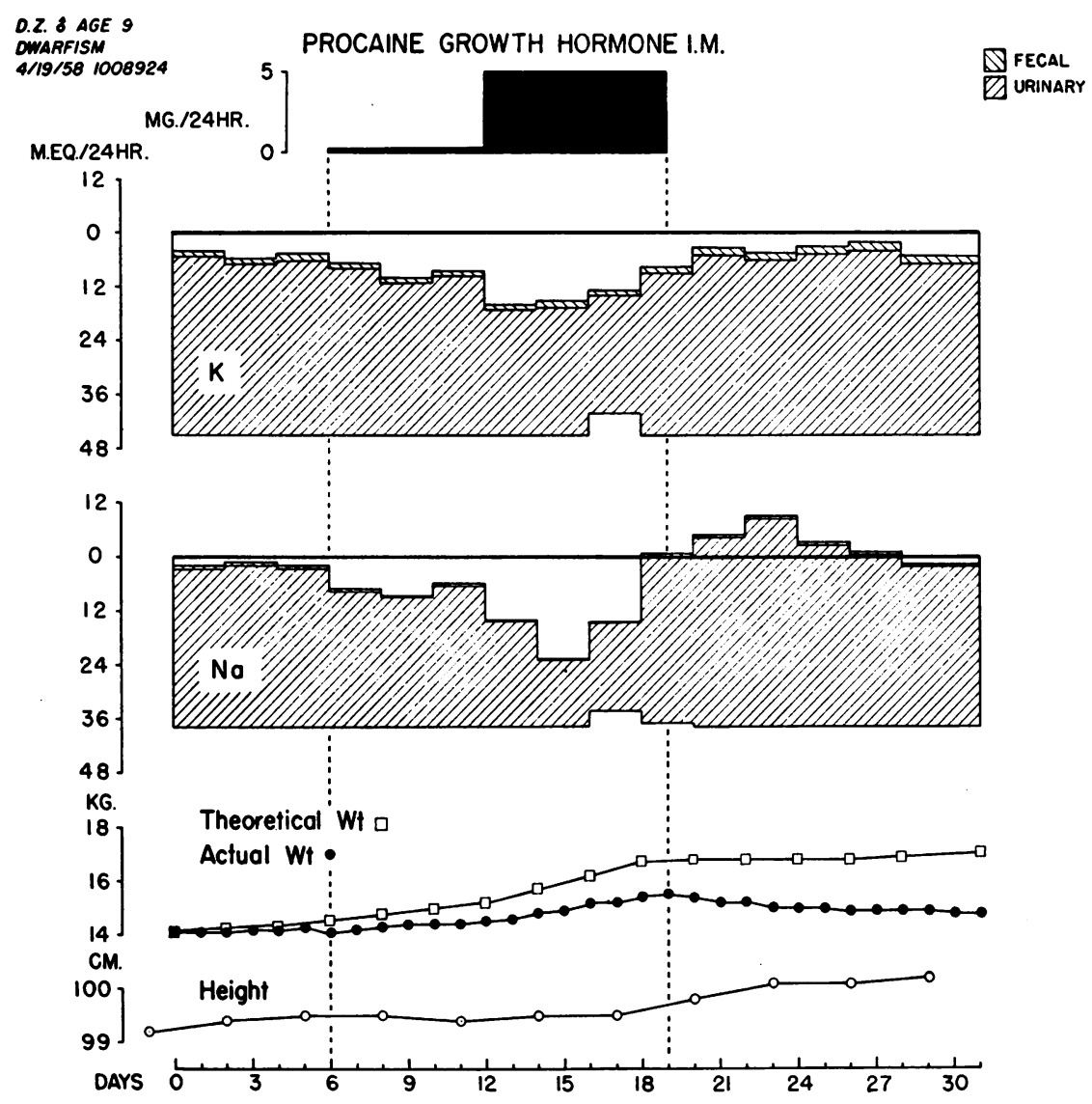

Fig. 7B. Potassium and sodium balances, height, and actual and theoretical WEIGHTS DURING HGH ADMINISTRATION TO D.Z.

be incomplete in patients with spontaneous Addison's disease, such sodium retention may have been the consequence of $\mathrm{HGH}$ stimulation of aldosterone secretion, as suggested by Beck and colleagues (1) or may indicate a direct renal action of $\mathrm{HGH}$ itself.

Prolonged HGH therapy in S.M. was attended by regrowth of a craniopharyngioma which apparently regressed on stopping $\mathrm{HGH}$ (see legend of Figure 1A). After 30 days' $\mathrm{HGH}$ administration M.A. developed evidence of third ventricle block which was attributed to further growth of her known craniopharyngioma. Further growth hormone therapy was withheld, a Torkildsen procedure for relief of internal hydrocephalus was carried out by Dr. J. C. White, and the patient has since continued in apparent good health for 18 months. Due to the irregular growth rate of craniopharyngiomas it is unclear whether $\mathrm{HGH}$ therapy really stimulated growth of these tumors. It is to be noted that partial removal of these tumors often inhibits their further significant growth. This effect might equally well be attributed to the hypopituitarism (and loss of growth hormone secretion) which commonly follows pituitary surgery.

\section{SUMMARY}

Daily intramuscular injections of 0.2 to $10 \mathrm{mg}$ daily of the Raben preparation of human growth hormone in 10 patients stimulated linear growth, produced retention of all cellular constituents measured, increased calcium absorption, and probably mobilized fat. At the dose levels used the chemical response to human growth hormone waned after 3 to 4 weeks' continuous treatment; responsiveness was restored by 12 days off growth hormone. As used in this study the Raben prepara- 
tion of human growth hormone was stable, well tolerated, apparently free of significant gonadotropic, thyrotropic and adrenocorticotropic contamination, and did not stimulate precipitating or blocking antibodies.

\section{REFERENCES}

1. Beck, J. C., McGarry, E. E., Dyrenfurth, I., and Venning, E. H. Metabolic effects of human and monkey growth hormone in man. Science 1957, $125,884$.

2. Ikkos, D., Luft, R., and Gemzell, C. A. The effect of human growth hormone in man. Lancet 1958, 1,720 .

3. Raben, M. S. Treatment of a pituitary dwarf with human growth hormone. J. clin. Endocr. 1958, 18, 901.

4. Pearson, O. H., Lipsett, M. B., Greenberg, E., and Ray, B. S. Effects of human growth hormone in hypophysectomized patients (abstract no. 40). Endocrine Society, 39th Annual Meeting, New York, 1957.

5. Henneman, P. H., Moldawer, M., Carroll, E. L., Mitchell, M., and Waddell, M. J. Human growth hormone: Prolonged administration of moderate doses in three patients with panhypopituitarism (abstract no. 40). Endocrine Society, 40th Annual Meeting, San Francisco, 1958.

6. Bergenstal, D. M., Lubs, H. A., Hallman, L. F., Patten, J., Levine, H. J., and Li, C. H. Metabolic effects of human and monkey growth hormone in man (abstract). J. Lab. clin. Med. 1957, 50, 791.

7. Panel appointed by the Clinical Endocrinology Committee of the Medical Research Council. The effectiveness in man of human growth hormone. Lancet 1959, $1,7$.

8. Raben, M. S. Preparation of growth hormone from pituitaries of man and monkey. Science 1957, 125, 883.

9. Wilhelmi, A. E., Fishman, J. B., and Russell, J. A. A new preparation of crystalline anterior pituitary growth hormone. J. biol. Chem. 1948, 176, 735.

10. Li, C. H., and Papkoff, H. Preparation and properties of growth hormone from human and monkey pituitary glands. Science 1956, 124, 1293.
11. Reifenstein, E. C., Jr., Albright, F., and Wells, S. L. The accumulation, interpretation, and presentation of data pertaining to metabolic balances, notably those of calcium, phosphorus and nitrogen. J. clin. Endocr. 1945, 5, 367.

12. Dempsey, E. F., Carroll, E. L., Albright, F., and Henneman, P. H. A study of factors determining fecal electrolyte excretion. Metabolism 1958, 7, 108.

13. Henneman, D. H., and Henneman, P. H. Effects of human growth hormone on levels of blood and urinary carbohydrate and fat metabolites in man. J. clin. Invest. 1960, 39, 1239.

14. Liddle, G. W., Richard, J. E., and Peterson, R. E. An improved method for assaying the steroidogenic potency of ACTH. Endocrinology 1955, 57, 594.

15. Robinson, J. F., Power, M. H., and Kepler, E. J. Two new procedures to assist in the recognition and exclusion of Addison's disease: A preliminary report. Proc. Mayo Clin. 1941, 16, 577.

16. Talbot, N. B., Sobel, E. H., McArthur, J. W., and Crawford, J. D. Functional Endocrinology from Birth through Adolescence. Cambridge, Mass., Harvard Univ. Press, 1952, pp. 595, 596.

17. Blodgett, F. M., Burgin, L., Iezzoni, D., Gribetz, D., and Talbot, N. B. Effects of prolonged cortisone therapy on the statural growth, skeletal maturation and metabolic status of children. New Engl. J. Med. 1956, 254, 636.

18. Lerman, J., (Massachusetts General Hospital). Personal communication.

19. Macy, I. G. Nutrition and Chemical Growth in Childhood. Springfield, Ill., Charles C Thomas, 1946, vol. 2.

20. Emerson, J. D., and Emerson, G. M. Effect of steroid dose and steroid ratio on plateauing in the adrenalectomized rat receiving a growth hormone-containing pituitary extract. Endocrinology 1957, 60, 393.

21. Bartter, F. C., Fourman, P., Albright, F., Forbes, A. P., Jeffries, W. McK., Griswold, G., Dempsey, E., Bryant, D., and Carroll, E. The effect of adrenocorticotropic hormone in panhypopituitarism. J. clin. Invest. 1950, 29, 950.

22. Batts, A. A., Bennett, L. L., Garcia, J., and Stein, J. The effect of growth hormone on muscle potassium and on extracellular fluid. Endocrinology 1954, 55, 456. 